\title{
Kualitas Sawo (Achras zapota L.) Kultivar Sukatali Selama Penyimpanan
}

\author{
Kusumiyati $^{1 *}$, Syariful Mubarok ${ }^{1}$, Wawan Sutari ${ }^{1}$, Farida $^{1}$, Yuda Hadiwijaya ${ }^{2}$ dan Ine Elisa \\ Putri $^{2}$ \\ ${ }^{1}$ Staf Pengajar Program Studi Agroteknologi Fakultas Pertanian Universitas Padjadjaran \\ ${ }^{2}$ Alumni Program Studi Agroteknologi Fakultas Pertanian Universitas Padjadjaran \\ Jl. Raya Bandung - Sumedang Km. 21 Jatinangor \\ *Alamat korespondensi: kusumiyati@gmail.com
}

\section{ABSTRACT \\ Quality of sapodilla (Achras zapota L.) cv. Sukatali during storage}

Sapodilla is tropical fruit which contains vitamin, mineral and antioxidant that needed for human health. Process after harvesting before reaching the consumers are includingdistributionto seller or retailer at the market. The purpose of this research aimed to analyze sapodilla quality during storage since harvest to the consumers, such as, firmness, moisture content, total dissolved solid and color. The research was conducted on March to July 2017 at the Laboratory of Horticulture Agriculture Faculty, Universitas Padjadjaran, Jatinangor. The method used in this experiment was Randomize Block Designed (RBD) with three treatments and nine replications. Total sample were 270 fruits. Sapodillas were harvested at the same maturity stage from the orchad, then stored for 0 , 5 , and 10 days indoor at room temperature. The result showed that storage duration has an effect to yield quality of sapodilla, specifically the changes at value of firmness, total dissolved solid, and color changes ( $L^{*}, a^{*}, b^{*}$, ${ }^{\circ}$ ue, and chroma).

Keywords: Moisture content, Firmness, Total dissolved solid

\begin{abstract}
ABSTRAK
Sawo merupakan buah tropik yang mengandung vitamin, mineral, dan antioksidan yang diperlukan untuk kesehatan manusia. Proses setelah panen sebelum sampai ke tangan konsumen, pada umumnya melalui jalur distribusi ke pedagang atau penjual di pasar. Tujuan dari penelitian ini adalah untuk menganalisis kualitas buah sawo selama penyimpanan dari mulai panen hingga di tangan konsumen. Komponen yang diamati meliputi kekerasan buah, kadar air, total padatan terlarut, dan warna. Penelitiandilakukan pada Maret sampai Juli 2017 di Laboratorium Teknologi Produksi Tanaman Divisi Hortikultura Fakultas Pertanian Universitas Padjadjaran, Jatinangor. Metode penelitian yang digunakan adalah metode rancangan acak kelompok (RAK) dengan 3 perlakuan diulang sebanyak 9 kali. Total sampel yang digunakan sebanyak 270 buah. Buah sawo dipanen dari kebun sawo pada stadia kematangan yang sama, lalu disimpan selama 0, 5 dan 10 hari dalam ruangan dengan suhu kamar. Hasil penelitian menunjukan bahwa lama penyimpanan berpengaruh terhadap kualitas hasil buah sawo, yaitu perubahan pada nilai kekerasan buah, kadar air, total padatan terlarut, dan perubahan warna ( $\mathrm{L}^{*}, \mathrm{~b}^{*}$, ${ }^{\circ}$ hue, dan chroma).
\end{abstract}

Kata kunci : Kadar air, Kekerasan buah, Total padatan terlarut

\section{PENDAHULUAN}

Buah-buahan merupakan produk hortikultura yang sangat diminati oleh masyarakat karena selain manis dan menyegarkan, buah-buahan juga banyak mengandung vitamin,mineral. dan antioksidan yang bermanfaat bagi kesehatan manusia.Sawo merupakan sayuran buah tropik dataran tinggi, tetapi banyak pula varietas yang dapat tumbuh baik di dataran rendah (Ashari, 2006). 
Pada tahun 2016, provinsi Jawa Barat menjadi produsen buah sawo terbesar di Indonesia dengan hasil produksi sebesar 22.308 ton/tahun, selanjutnya disusul oleh provinsi Lampungdengan hasil produksi sebesar 15.468 ton/tahun, selanjutnya provinsi Jawa Tengah dengan hasil produksi sebesar 13.558 ton/tahun (BPS, 2016).

Di Indonesia terdapat berbagai kultivar sawo, beberapa kultivar sawo yang komersial dan banyak diusahakan oleh petani adalah sawo Sukatali (Sumedang, Jawa Barat). Jenis tanah yang cocok untuk tanaman sawo diantaranya yaitu aluvial, latosol dan andosol, dan kemasaman tanah yang optimal yaitu 6-7 (Kusmiyati dkk., 2014)

Sejauh ini buah sawo dari Indonesia belum banyak diekspor keluar negeri. Hasil panen dari buah sawo di Indonesia masih lebih difokuskan untuk memenuhi kebutuhan dalam negeri saja. Perkembangan produksi buah sawo mengalami peningkatan, namun sampai saat ini belum memenuhi kebutuhan masyarakat (BAPPENAS, 2005).

Analisa penurunan kualitas buah memerlukan suatu parameter yang dapat diukur secara kuantitatif. Syarief \& Halid (1994) melaporkan bahwa warna, tekstur, dan kandungan gula dapat dijadikan parameter untuk menilai penurunan kualitas buah. Pada umumnya penilaian penurunan mutu dilakukan dengan menilai dari kekerasan dan warna buah.

Tingkat kekerasan pada buah sawo dipengaruhi oleh beberapa faktor seperti ketegangan buah. Selain itu pula tergantung pada ketebalan kulit luar buah, total padatan terlarut dan kandungan pati (Pantastico, 1986). Ketika buah sawo berada pada stadia matang maka tingkat kemanisan buah akan berbanding terbalik dengan kadar kemasaman. Saat mengalami proses pematangan, tingkat kemasaman buah akan cenderung rendah (Pantastico, 1993).

Sawo merupakan buah klimaterik dimana lonjakan etilen dan respirasi dapat terjadi setelah buah dipanen. Selama umur penyimpanan 5 sampai 10 hari kandungan etilen dan proses respirasi dapat menyebabkan terjadinya perubahan kualitas buah sawo. Pada kondisi matang, buah sawo hanya dapat selama 3-5 hari saja. Setelah itu buah akan menjadi terlalu matang (Agustiningrum dkk., 2014). Oleh karena itu sawo umumnya dipanen sebelum matang sehingga perlu dilakukan pemeraman selama beberapa hari. Penanganan yang tepat selama proses distribusi ke pedagang atau penjual di pasar juga diperlukan sehingga diharapkan tidak terjadi penurunan kualitas atau tidak layak dikonsumsi pada saat sampai di tangan konsumen.

\section{BAHAN DAN METODE}

Penelitian ini dilakukan pada Maret sampai Juli 2017 di Laboratorium Teknologi Produksi Tanaman Divisi Hortikultura Fakultas Pertanian Universitas Padjadjaran, Jatinangor. Bahan utama yang digunakan pada penelitian ini adalah buah sawo pada tingkat kematangan yang sama dan biasa dipanen oleh petani dengan bentuk buah normal, kulit buah berwarna coklat, dan mudah dipetik dari pohonnya namun teksturnya masih keras. Alat yang digunakan pada penelitian ini ada tension gauge, refraktometer, oven, dan chroma meter.

Metode penelitian yang digunakan adalah metode rancangan acak kelompok (RAK) dengan 3 perlakuan dan 9 ulangan. Penggunaan RAK dikarenakan setelah didestruksi, sample yang sama tidak digunakan dalam pengukuran pada hari pengamatan berikutnya. Perlakuan pertama adalah penyimpanan sawo selama 0 hari $\left(\mathrm{H}_{0}\right)$. Perlakuan kedua adalah penyimpanan sawo selama 5 hari $\left(\mathrm{H}_{5}\right)$. Perlakuan ketiga adalah penyimpanan sawo selama 10 hari ( $\left.\mathrm{H}_{10}\right)$.

Penyimpanan dilakukan di dalam ruangan pada suhu kamar. Sampel yang digunakan sebanyak 270 sampel buah sawo kultivar Sukatali dengan masing-masing perlakuan terdiri dari 90 sampel. Buah sawo yang digunakan berasal dari Desa Sukatali, Kecamatan Situraja, Sumedang. Buah sawo telah dipanen kemudian dibersihkan dengan cara digosok menggunakan kain kering untuk menghilangkan getah dan kotoran pada kulit buah. Pengamatan yang dilakukan meliputi kekerasan buah, kadar air, total padatan terlarut, dan warna $\left(\mathrm{L}^{*}\right.$, $a^{*}, b^{*}$, ohue dan chroma).Kekerasan buah diukur dengan menggunakan tension gauge (AND Model AD-4932A-50 N, Taiwan) dengan cara menusukannya ke bagian tengah buah. Maka akan didapat nilai kekerasan buah dengan satuan Newton (N).

Warna buah diukur dengan menggunakan chromameter, kemudian didapatkan nilai L*, a*, b*. Nilai $\mathrm{L}^{*}$ mendeskripsikan kecerahan warna, dimana 0 untuk hitam dan 100 putih. Nilai a* menunjukkan jenis warna hijau - merah, dimana negatif a* merupakan warna hijau, sedangkan positif $a^{*}$ merupakan warna merah. Nilai $b^{*}$ menunjukkan jenis warna biru - kuning, dimana negatif $b^{*}$ merupakan warna biru, sedangkan positif $b^{*}$ adalah warna kuning. Pengukuran warna buah diambil 
dari dua sisi yang berbeda dari buah sawo, dalam setiap sisi masing-masing diukur pada bagian atas, tengah dan bawah dari buah sawo. Bagian atas yang dimaksud adalah bagian yang menempel pada tangkai buah sawo.

Pengukuran total padatan terlarut dihitung dari sari hasil parutan buah dan dihitung menggunakan refractrometer (PR1 Atago, Japan). Hasil pengukuran total padatan terlarut dinyatakan dalam\%brix (Ismawati dkk., 2016).Pengukuran total padatan terlarut buah diambil dari bagian atas, tengah dan bawah dari buah sawo.

Pengukuran kadar air dilakukan dengan menggunakan metode gravimetri.Buah diiris lalu dimasukan dalam cup aluminium foil, dikeringkan didalam oven bersuhu $80^{\circ} \mathrm{C}$ sampai berat buah konstan. Kandungan air dari buah dinyatakan dalam \% berat basah. Sebelum dan setelah dimasukkan ke dalam oven ditimbang untuk menentukan kadar air buah segar. Pengukuran kadar air buah diukur pada bagian atas, tengah dan bawah dari buah sawo.Semua pengukuran buah dilakukan di laboratorium.

\section{HASIL DAN PEMBAHASAN}

Waktu penyimpanan buah sawo memengaruhi tingkat kekerasan buah. Hasil pengukuran terhadap kekerasan buah yang disimpan sesuai perlakuan waktu simpan disajikan pada Tabel 1.Buah sawo yang tidak disimpan tingkat kekerasannya mencapai 22,22856 N, sementara setelah disimpan 5 hari dan 10 hari, tingkat kekerasannya menurun sampai hampir 50\%. Hal tersebut dikarenakan buah yang diberi perlakuan penyimpanan terus melakukan proses respirasi sehingga memengaruhi nilai kekerasan buah. Syafutri (2006) melaporkan bahwa selama proses respirasi terjadi pemecahan karbohidrat dalam buah yang mengakibatkan buah menjadi lunak. Penurunan nilai kekerasan buah ini sudah terjadi sejak buah sawo disimpan selama 5 hari. Pada umumnya sawo dipanen pada waktu buah masih keras kemudian diperam 2 atau 3 hari, baru dikategorikan buah sawo yang layak untuk dikonsumsi. Sawo yang matang di pohon biasanya rusak oleh lalat buah atau kelelawar sebelum sempat dipanen.

Tabel 1. Pengaruh lama penyimpanan terhadap nilai rata-rata kekerasan, kadar air dan total padatan terlarut buah sawo.

\begin{tabular}{lccc}
\hline \multicolumn{1}{c}{ Perlakuan } & Kekerasan buah $(\mathrm{N})$ & Kadar air $(\%)$ & Total padatan terlarut (\%) \\
\hline Penyimpanan 0 hari (Ho) & $22,22856 \mathrm{a}$ & $70,165 \mathrm{a}$ & $24,77399 \mathrm{a}$ \\
Penyimpanan 5 hari (H5) & $13,43189 \mathrm{~b}$ & $70,667 \mathrm{a}$ & $22,67802 \mathrm{~b}$ \\
Penyimpanan 10 hari (H10) & $12,58622 \mathrm{~b}$ & $71,988 \mathrm{a}$ & $20,65387 \mathrm{c}$ \\
\hline
\end{tabular}

Keterangan: Nilai yang ditandai huruf yang sama pada kolom yang sama menunjukan bahwa nilai tersebut tidak berbeda nyata menurut uji jarak berganda Duncan pada taraf 5\%.

Nilai kadar air pada buah merupakan salah satu parameter untuk menentukan ketahanan simpan buah. Pengujian kadar air tidak menunjukkan adanya perbedaan yang nyata pada berbagai waktu simpan perlakuan $\mathrm{H}_{0}, \mathrm{H}_{5}$, dan $\mathrm{H}_{10}$. Namun, total padatan terlarut pada masing-masing perlakuan waktu simpan buah sawo menunjukkan perbedaan yang nyata satu dengan yang lainnya. Nilai total padatan terlarut pada Tabel 1 merupakan nilai rata-rata bagian atas, tengah, dan bawah buah. Semakin lama buah sawo disimpan, maka semakin rendah pula nilai total padatan terlarutnya. Nilai padatan terlarut bagian bawah merupakan bagian tertinggi nilai kadar padatan terlarutnya dibandingkan dengan kadar air pada bagian atas dan tengah, hal ini dikarenakan bahan-bahan hasil fotosintesis dan serapan hara (source) dialirkan dan bermuara pada buah bagian terbawah (sink). Bagian buah sawo yang terbawah akan matang lebih dahulu dibandingkan bagian tengah kemudian bagian atas, tempat melekatnya tangkai buah. Penurunan nilai total padatan terlarut selama penyimpanan diakibatkan oleh penurunan kandungan getah yang terdapat pada buah sawo. Degradasi kandungan getah pada buah selama proses pematangan juga terjadi pada buah apel (Winarno, 2002). Nasution (2012) menyebutkan bahwa penurunan total padatan terlarut selama masa simpan terjadi pada buah nanas. 
Tabel 2. Pengaruh lama penyimpanan terhadap nilai kecerahan buah sawo (L'), hijau-merah (a") dan birukuning $\left(b^{*}\right)$.

\begin{tabular}{lccc}
\hline \multicolumn{1}{c}{ Perlakuan } & Kecerahan buah $\left(\mathrm{L}^{*}\right)$ & Hijau-merah $\left(\mathrm{a}^{*}\right)$ & Biru-kuning $\left(\mathrm{b}^{*}\right)$ \\
\hline Penyimpanan 0 hari $\left(\mathrm{H}_{0}\right)$ & $57,34557 \mathrm{a}$ & $4,78663 \mathrm{a}$ & $26,71365 \mathrm{a}$ \\
Penyimpanan 5 hari $\left(\mathrm{H}_{5}\right)$ & $54,97231 \mathrm{~b}$ & $6,10024 \mathrm{~b}$ & $22,25767 \mathrm{~b}$ \\
Penyimpanan 10 hari $\left(\mathrm{H}_{10}\right)$ & $50,86469 \mathrm{c}$ & $5,13763 \mathrm{ab}$ & $21,65131 \mathrm{~b}$ \\
\hline
\end{tabular}

Keterangan: Nilai yang ditandai huruf yang sama pada kolom yang sama menunjukan bahwa nilai tersebut tidak berbeda nyata menurut uji jarak berganda Duncan pada taraf $5 \%$.

Nilai L* menunjukkan tingkat kecerahan warna buah sawo. Tabel 2 menunjukkan bahwa nilai $\mathrm{L}^{\prime}$ pada perlakuan $\mathrm{H}_{0}, \mathrm{H}_{5}$, dan $\mathrm{H}_{10}$ masing-masing berbeda nyata satu sama lain. Maka dari tabel tersebut dapat dilihat bahwa semakin lama penyimpanan buah sawo, semakin rendah pula tingkat kecerahan buah tersebut. Berkurangnya tingkat kecerahan warna pada buah sawo selama penyimpanan diakibatkan oleh berkurangnya kandungan klorofil pada kulit buah sawo dan munculnya karotenoid (Syafutri dkk., 2006)

Nilai a merupakan nilai yang menunjukkan gradasi warna hijau menuju ke warna merah. Nilai a* negatif maka buah sawo berwarna hijau, nilai a positif, maka buah sawo tidak berwarna hijau (biasanya menunjukkan warna merah). Pada parameter a dapat dilihat bahwa perlakuan $\mathrm{H}_{0}$ berbeda nyata dengan perlakuan $\mathrm{H}_{5}$. Namun pada perlakuan $\mathrm{H}_{10}$ tidak berbeda nyata dengan perlakuan $\mathrm{H}_{0}$ dan $\mathrm{H}_{5}$. Pada waktu penyimpanan 5 dan 10 hari warna hijau (kecoklatan) pada buah sawo tidak berbeda, namun pada waktu dipanen, buah sawo tersebut masih lebih hijau (kecoklatan).

Penentuan panen buah sawo diantaranya ditentukan dengan cara melihat perubahan warna dari hijau ke coklat, bukan berdasarkan perhitungan hari setelah berbunga. Menurut informasi dari petani sawo di daerah Sukatali, Sumedang, perhitungan hari setelah berbunga tidak dijadikan patokan karena sawo memerlukan waktu sekitar 5-6 bulan untuk dapat dipanen. Perhitungan hari setelah berbunga harus menandai setiap bunga yang akan menjadi buah juga tidak praktis diaplikasikan karena posisi bunga berada di pohon yang tinggi dan sulit untuk dijangkau, terlebih lagi untuk ditandai. Sehingga pemilihan panen buah sawo ditentukan secara visual dengan ciri yaitu ukuran buah sudah maksimal, warna buah bagian luar berwarna coklat muda, bila diraba bagian buahnya agak lembek, bila buah dipetik dari tangkainya mudah lepas, dan getahnya sedikit. Penentuan panen secara visual dengan melihat perubahan fisiologis menjadi subjektif, bila pemanen berpengalaman maka penentuan waktu panen mungkin akan lebih tepat. Sawo yang dipanen matang buah biasanya rusak oleh lalat buah atau kelelawar, tetapi pemanenan buah yang muda rasa buahnya tidak manis atau sepat sehingga memerlukan waktu yang lama untuk disimpan sampai matang. Variasi kualitas buah yang dipanen pada buah sawo sangat besar dikarenakan belum ditemukan metoda yang tepat dan mudah diaplikasikan di lapangan.

Tabel 2 menunjukkan nilai $b^{*}$ pada perlakuan $\mathrm{H}_{0}$ berbeda nyata dengan perlakuan $\mathrm{H}_{5}$ dan $\mathrm{H}_{10}$, sedangkan perlakuan $\mathrm{H}_{5}$ dan $\mathrm{H}_{10}$ tidak berbeda nyata. Nilai $b^{*}$ menunjukkan gradasi warna menuju ke warna kuning. Nilai $b^{*}$ negatif menunjukkan warna buah kebiruan, sebaliknya nilai $\mathrm{b}^{*}$ positif menunjukkan warna buah kekuningan. Penyimpanan buah sawo mengakibatkan degradasi warna kuning pada buah sawo. Secara visual buah sawo muda berwarna coklat muda atau perspektif warna b* kuning. Semakin lama buah sawo disimpan berubah menjadi gelap (berwarna coklat tua) dalam perspektif warna $b^{*}$ biru.

Tabel 3. Pengaruh lama penyimpanan terhadap nilai ${ }^{\circ}$ hue dan chroma sawo.

\begin{tabular}{lcc}
\hline \multicolumn{1}{c}{ Perlakuan } & ohue & Chroma \\
\hline Penyimpanan 0 hari $\left(\mathrm{H}_{0}\right)$ & $75,49510 \mathrm{a}$ & $27,30946 \mathrm{a}$ \\
Penyimpanan 5 hari $\left(\mathrm{H}_{5}\right)$ & $70,46531 \mathrm{~b}$ & $23,30815 \mathrm{~b}$ \\
Penyimpanan 10 hari $\left(\mathrm{H}_{10}\right)$ & $68,48427 \mathrm{~b}$ & $22,53771 \mathrm{~b}$ \\
\hline
\end{tabular}

Keterangan : Nilai yang ditandai huruf yang sama pada kolom yang sama menunjukan bahwa nilai tersebut tidak berbeda nyata menurut uji jarak berganda Duncan pada taraf $5 \%$. 
Pada parameter ohue dapat dilihat bahwa pada perlakuan $\mathrm{H}_{0}$ berbeda nyata dengan perlakuan $\mathrm{H}_{5}$ dan $\mathrm{H}_{10}$. Pada perlakuan $\mathrm{H}_{5}$ tidak berbeda nyata dengan perlakuan $\mathrm{H}_{10}$. ${ }^{\circ} \mathrm{Hue}$ adalah karakteristik warna yang didasarkan pada cahaya yang dipantulkan oleh buah sawo, rentang nilai ohue berkisar 0 hingga 359 . Nilai 0 menunjukan warna merah, nilai 60 yaitu warna kuning, untuk warna hijau berkisar pada nilai 120, pada nilai 180 merupakan warna biru kehijauan. Pada nilai 240 merupakan warna biru, dan 300 adalah warna merah mudah keunguan (DeMann, 1989). Kisaran nilai $68-75^{\circ}$ hue merupakan nilai pada kisaran warna kuning dan hijau (60-120). Pada waktu dipanen warna buah sawo masih hijau kecoklatan akan tetapi setelah buah sawo disimpan selama 5 dan 10 hari terdapat perubahan warna antara hijau (kecoklatan) dan kuning (kecoklatan).

Nilai chroma pada perlakuan $\mathrm{H}_{0}$ berbeda nyata dengan perlakuan $\mathrm{H}_{5}$ dan $\mathrm{H}_{10}$. Namun pada perlakuan $\mathrm{H}_{5}$ tidak berbeda nyata dengan perlakuan $\mathrm{H}_{10}$. Chroma merupakan nilai intensitas warna pada buah sawo. Semakin tinggi nilai chroma maka semakin cerah warna buah sawo, sebaliknya semakin rendah nilai chroma maka semakin kusam warna buah sawo. Terik cahaya matahari pada waktu buah sawo dipanen $\left(\mathrm{H}_{0}\right)$ masih memberikan dampak warna cerah pada buah, tetapi setelah disimpan 5 dan 10 hari dalam ruangan terjadi perubahan kecerahan warna buah yang semakin berkurang.

\section{SIMPULAN DAN SARAN}

Penyimpanan lima dan sepuluh hari setelah buah sawo dipanen memberikan pengaruh pada kualitas buah sawo pada nilai kekerasan buah, total padatan terlarut dan, $\mathrm{L}^{*}, \mathrm{a}^{*}, \mathrm{~b}^{*}$, ohue, chroma dibandingkan pada waktu panen. Namun nilai kadar air pada saat panen maupun setelah disimpan 10 hari tidak mengalami perubahan.

\section{DAFTAR PUSTAKA}

Agustiningrum, DA, B Susilo dan R Yulianingsih. 2014. Studi pengaruh konsentrasi oksigen pada penyimpanan atmosfer termodifikasi buah sawo (Achras zapota L.) Jurnal Bioproses Komoditas Tropis 2 (1): 22-34.

Ashari, S. 2006. Hortikultura Aspek Budidaya. UIPress. Indonesia. 490 hal.

Badan Pusat Statistik (BPS). 2016. Produksi Tanaman Hortikultura. Tersedia online pada https://www.bps.go.id/site/resultTab (diakses pada 8 Agustus 2017).

BAPPENAS. 2005. Teknologi Tepat Guna Warintek - Menteri Negara Riset dan Teknologi. TTG-Budidaya Pertanian Sawo.

DeMann, JM. 1989. Principles of Food Chemistry. Wadsworth,Inc : Canada

Ismawati, N, Nurwantoro, dan YB Pramono. 2016. Nilai $\mathrm{pH}$, total padatan terlarut dan sifat sensoris yoghurt dengan penambahan ekstrak bit (Beta vulgaris L.). Jurnal Aplikasi Teknologi Pangan 5 (3): 89-93.

Kusmiyati, ED, Trisnowati, S dan Ambarwati, E. 2014. Kajian budidaya dan produktivitas sawo (Manilkarazapota (1.) Van Royen) di Dusun Pasutan, Bogoran dan Pepe, Desa Trirenggo, Kabupaten Bantul, Yogyakarta. Vegetalika 3 (1): 66-78.

Nasution, IS, Yusmanizar dan M Kurnia. 2012. Pengaruh penggunaan lapisan edibel (edible coating), kalsium klorida dan kemasan plastik terhadap mutu nanas (Ananas comosusMerr.) terolah minimal. J. Teknologi dan Industri Pertanian Indonesia. 4 (2): 21-26.

Pantastico, Er, TL Chattpadhayay dan H Subramayan 1986. Fisiologi Pasca Panen. Gadjah Mada University Press. Yogyakarta.

Pantastico, ErB. 1993. Postharvest Physiology, Handling and Utilization of Tropical and Sub-Tropical Fruits and Vegetables. (Fisiologi Pascapanen, Penanganan dan Pemanfaatan Buah-buahan dan Sayursayuran Tropika dan Subtropika, alih bahasa Kamariyani). Gadjah Mada University Press, Yogyakarta.

Suyanti, S, AB Roosmani dan ST Sjaifullah. 1999. Pengaruh tingkat ketuaan terhadap mutu pascapanen buah manggis selama penyimpanan. J. Hortukultura. 1(3): 51-58.

Syafutri, MI, F Pratama dan D Saputra. 2006. Sifat dan kimia buah mangga (Mangifera indica L.) selama penyimpanan dengan berbagai metode pengemasan. Jurnal Teknologi dan Industri Pangan XVII (1).

Syarief, R, dan H Halid. 1994. Teknologi Penyimpanan Pangan. Penerbit Arcan. Jakarta.

Winarno, FG. 2002. Kimia Pangan dan Gizi. Gramedia Pustaka Utama. Jakarta. 